\title{
Anticancer effects of CAMEL peptide
}

\author{
Ryszard Smolarczyk ${ }^{1}$, Tomasz Cichoń ${ }^{1}$, Wojciech Kamysz², Magdalena Głowala-Kosińska ${ }^{3}$ Anna Szydło ${ }^{4}$, \\ Łukasz Szultka ${ }^{2}$, Aleksander L Sieroń ${ }^{4}$ and Stanisław Szala ${ }^{1}$
}

This study analyzed whether therapy with CAMEL, an antimicrobial peptide (KWKLFKKIGAVLKVL), possess anticancer benefits. Although the peptide was cytotoxic for all the cell lines tested, it did not cause hemolysis, which suggests that CAMEL does not damage cell membranes. After cellular internalization, CAMEL localized to mitochondria and lowered the mitochondrial potential, resulting in the organelles' swelling, a decrease in cellular ATP level and, finally, cellular breakdown. High mobility group box 1 (HMGB1) protein, a necrotic death marker, was shown to be released from cells treated with CAMEL. Growth of B16-F10 melanoma tumors was clearly restrained after injections with CAMEL and could be kept in check throughout the period of peptide administration. However, if therapy was stopped, tumors started to grow again 3-4 days later. To reduce tumor volume and block tumor relapse, a combined therapy was required involving CAMEL and plasmid DNA carrying the interleukin-12 (IL-12) gene. The two therapeutic agents used in combination (a series of CAMEL injections first, followed by daily administration of plasmid DNA) delayed tumor growth and extended survival of treated animals in a statistically significant manner. Complete tumor regression was found in $60 \%$ of cases. Laboratory Investigation (2010) 90, 940-952; doi:10.1038/labinvest.2010.58; published online 8 March 2010

KEYWORDS: anticancer therapy; CAMEL peptide; combined therapy; immunotherapy; necrosis

Recent data indicate that antimicrobial peptides can be useful for anticancer therapeutic purposes. ${ }^{1}$ Such peptides consist of a dozen to a hundred of amino acids and are positively charged. $^{2}$ They are isolated from microorganisms and certain insect, plant, fish, reptile, bird or mammalian cells, including human cells. Some of these peptides are synthetic.

Antimicrobial peptides are part of a congenital, nonspecific and evolutionarily ancient form of immune response to various pathogens. ${ }^{2}$ In several species such peptides are synthesized continuously, for example, in the hemolymph of insects or by cells of the vertebrate immune system. Some of these peptides, however, can be synthesized de novo as a result of contact with a specific pathogen. Antimicrobial peptides kill eukaryotic cells by destroying their cell membranes or mitochondrial membranes. ${ }^{1}$

As a result of differences in cell membrane structure, larger surface area and the presence of villi, neoplastic cells are penetrated by antimicrobial peptide more selectively than normal cells. ${ }^{3}$

The advantages offered by these highly specific substances, together with ease of synthesis and possibility of amino acid modifications, facilitate the design of novel peptides with desired therapeutic properties. ${ }^{4}$ Thanks to their small size, such peptides are capable of deeply penetrating target tissues. ${ }^{5}$ In addition, suitably designed and constructed peptides can feature sequences that allow peptide binding to respective cellular targets in a highly specific manner. ${ }^{6}$

One of the shortcomings of these peptides is their limited circulation lifetime. A short linear peptide is rapidly degraded, with its halftime in the blood not exceeding 2-5 min. Longer peptides are more stable and have lifetime exceeding 1 to $2 \mathrm{~h}^{4}$. Additional therapeutic benefit of using peptides instead of whole proteins stems from the fact that peptides are less immunogenic.

The major aim of this study was to evaluate anticancer potential of an antimicrobial peptide named CAMEL. ${ }^{7}$ This construct, abbreviated as CA(1-7) M(2-9), is made up of two fragments. One is derived from cecropin A (amino acids CA (1-7)), a peptide occurring in Hyalophora cecropia hemolymph and the other from melittin (amino acids M (2-9)), a peptide from Apis mellifera (honeybee). CAMEL is an antimicrobial compound active against both Gram-positive and

\footnotetext{
${ }^{1}$ Department of Molecular Biology, Maria Skłodowska-Curie Memorial Cancer Center and Institute of Oncology, Gliwice, Poland; ${ }^{2}$ Department of Inorganic Chemistry, Faculty of Pharmacy, Medical University of Gdańsk, Gdańsk, Poland; ${ }^{3}$ Department of Tumor Biology, Maria Skłodowska-Curie Memorial Cancer Center and Institute of Oncology, Gliwice, Poland and ${ }^{4}$ Department of General, Molecular Biology and Genetics, Medical University of Silesia, Gliwice, Poland

Correspondence: R Smolarczyk, PhD, Department of Molecular Biology, Maria Skłodowska-Curie Memorial Cancer Center and Institute of Oncology, Gliwice Branch, 44-101 Gliwice, ul. Wybrzeże Armii Krajowej 15, Poland.

E-mail: rsmolarczyk@io.gliwice.pl

Received 8 April 2009; revised and accepted 16 December 2009
} 
Gram-negative bacteria and is more potent than either of its components separately. The hybrid peptide has no hemolytic activity, unlike melittin. We were also interested in the effects that CAMEL exerts upon specific eukaryotic cells in culture and in testing its therapeutic efficacy against experimental murine melanoma tumors. To test the prevention of tumor relapse we also evaluated a regimen of combined anticancer therapy based on the use of CAMEL and interleukin-12 (IL-12) gene-carrying plasmid DNA.

\section{MATERIALS AND METHODS Peptide Synthesis}

CAMEL (KWKLFKKIGAVLKVL-NH ${ }_{2}$ ) and control peptide (YGWVLNESTILIFPK-NH $\mathrm{NH}_{2}$ ) were synthesized using 9-fluorenylmethoxycarbonyl solid-phase chemistry. ${ }^{8}$ The peptide was purified by solid-phase extraction on Kromasil sorbent $(\mathrm{C} 8,5 \mu \mathrm{m}, 100 \AA)$ using the protocol described elsewhere. ${ }^{9}$ The purity of resulting fractions ( $\left.>95-97 \%\right)$ was verified by using reversed-phase HPLC. The peptide was further analyzed for its physical-chemical properties using matrix-assisted laser desorption ionization time-of-flight mass spectrometry (MALDI-TOF).

\section{Peptide Cytotoxicity}

Cultures of B16-F10 murine melanoma, RENCA murine renal carcinoma, 4T1 murine mammary carcinoma, WM1158 human melanoma, NIH3T3 murine fibroblasts, Wi38 human fibroblasts as well as HECa10 and HEC PP murine endothelial cells were subjected to MTT (3-(4,5-dimethylthiazol-2-yl)-2,5-diphenyltetrazolium bromide) test to determine the number of surviving cells after treatment with CAMEL. The cells were plated in 96-well NUNCLON ${ }^{\mathrm{TM}}$ Surface $\left(\mathrm{NUNC}^{\mathrm{TM}}\right)$ vessels $\left(3-5 \times 10^{3}\right.$ cells/well) using RPMI1640 medium supplemented with $10 \%$ fetal bovine serum (FBS) and were incubated under standard conditions $\left(37^{\circ} \mathrm{C} /\right.$ $5 \% \mathrm{CO}_{2}$, relative humidity 95\%). After $24 \mathrm{~h}$, the growth medium was replaced with fresh medium containing various concentrations of CAMEL and control peptide (1-20 $\mu \mathrm{M}$, in quadruplicate). Fresh medium without peptide was added to controls. The plates were incubated for additional $24 \mathrm{~h}$. Next, after medium removal, $100 \mu \mathrm{l}$ of MTT solution $(0.5 \mathrm{mg} / \mathrm{ml}$ in $\mathrm{PBS}^{-}$) was added to each well and plates were incubated for $3 \mathrm{~h}$ at $37^{\circ} \mathrm{C}$. Subsequently, $100 \mu \mathrm{l}$ of $0.125 \% \mathrm{HCl}$ in isopropanol was added to each well. To assess the percentage of live cells in samples, absorbance $(\lambda=570 \mathrm{~nm})$ was read using $\mathrm{EL}_{\mathrm{x}} 800$ spectrophotometric plate reader (Bio-Tek Instruments).

\section{Erythrocyte Hemolysis after CAMEL Administration}

Blood samples were collected from C57BL/6 strain mice using Vacutainer K2E test tubes containing EDTA (Becton Dickinson). The samples were then centrifuged and the morphotic elements rinsed twice with $\mathrm{PBS}^{-}$(Dulbecco's PBS without $\mathrm{Ca}^{2+}$ and $\mathrm{Mg}^{2+}$ ions). A $10 \%$ erythrocyte suspension was incubated with increasing doses of CAMEL peptide
(1-100 $\mu \mathrm{M})$. PBS $^{-}$was used as negative control and $1 \%$ Triton X-100 in water as positive control, respectively. The samples were centrifuged after incubation at $37^{\circ} \mathrm{C}(30 \mathrm{~min}$, $2 \mathrm{~h}$ and $24 \mathrm{~h}$ ) and supernatants transferred into a 96-well plate to assay erythrocyte lysis (spectrophotometric reading at $\lambda=405 \mathrm{~nm})$.

\section{Release of Lactate Dehydrogenase (LDH) from Murine Melanoma Cells}

The cells were plated in 96-well NUNCLON Surface (NUNC) vessels $\left(4 \times 10^{3}\right.$ cells/well $)$ using RPMI-1640 medium supplemented with $10 \%$ FBS and were incubated under standard conditions $\left(37^{\circ} \mathrm{C} / 5 \% \mathrm{CO}_{2}\right.$, relative humidity 95\%). Next, culture medium was switched to medium containing CAMEL (f.c. $=2.5$ and $10 \mu \mathrm{M}$ ), with the exception of controls to which only fresh culture medium was added. For each group, experiments were carried out in triplicate. After 5, 10, 30, 60 and $120 \mathrm{~min}$ the culture medium was collected and centrifuged. Aliquots $(50 \mu \mathrm{l})$ of the media were then incubated with $50 \mu \mathrm{l}$ Reaction Buffer (CytoTox 96 Non-Radioactive Cytotoxicity Assay kit, Promega). After 30-min incubation (RT) of light-protected samples, a $50 \mu \mathrm{l}$ Stop Solution was added to each well of the 96-well plate. Absorbance $(\lambda=490 \mathrm{~nm})$ was read using $\mathrm{EL}_{\mathrm{x}} 800$ spectrophotometric plate reader (Bio-Tek Instruments). Cells treated with Lysis Solution were used as positive control. The released LDH was also measured for cells not treated with the peptide (background control) as well as in the medium alone. Cytotoxicity of the peptide was determined vs reference (Lysis Buffertreated cells, 100\%).

\section{Cellular Localization of CAMEL}

To localize CAMEL in treated cells, a fluorescein isothiocyanate (FITC)-peptide conjugate was used (synthesized by GenScript). B16-F10 murine melanoma cells $\left(2 \times 10^{5}\right)$ were plated in $3-\mathrm{cm}$ dishes and left overnight. Next, culture medium in wells was switched to medium containing FITC-conjugated CAMEL $(10 \mu \mathrm{M})$ and propidium iodide $(0.5 \mu \mathrm{g} / \mathrm{ml})$. Pictures of cell cultures were taken every $2 \mathrm{~min}$ using Nikon Eclipse 80i fluorescent microscope equipped with FITC and TRITC filters (see Supplementary Data).

To show specificity of CAMEL binding to mitochondria, the latter were isolated from liver according to a protocol described elsewhere. ${ }^{10}$ In brief, livers were placed in a buffer (20 mM Tris pH 7.5, $10 \mathrm{mM} \mathrm{KCl,} 2 \mathrm{mM} \mathrm{MgCl} 2,1 \mathrm{mM}$ DTT, $0.5 \mathrm{mM}$ EDTA, pH 8.0, 5\% glycerol), cut into pieces and homogenized with a teflon-type homogenizer. The homogenate was centrifuged twice at $800 \mathrm{~g}$ for $10 \mathrm{~min}$ at $4{ }^{\circ} \mathrm{C}$ and then at $10000 \mathrm{~g}$ for $15 \mathrm{~min}$ at $4{ }^{\circ} \mathrm{C}$. The pellet was washed with buffer, centrifuged again as above and finally resuspended in the buffer indicated above. The mitochondria were then incubated for $10 \mathrm{~min}$ with FITC-labeled CAMEL $(5 \mu \mathrm{M})$ and MitoTracker Red CMXRos (Invitrogen) solution $(500 \mathrm{nM})$ and flow cytometry analysis was performed (FACS Canto instrument, Becton Dickinson). 


\section{Determination of Mitochondrial Transmembrane Potential}

B16-F10 murine melanoma cells were plated into six-well NUNCLON Surface (NUNC) dishes $\left(5 \times 10^{5}\right.$ cells $)$ using $3 \mathrm{ml}$ culture medium per well. The cultures were left for $24 \mathrm{~h}$ in a standard incubator. Next, culture medium was switched to medium containing CAMEL $(2.5,5$ and $10 \mu \mathrm{M})$ with the exception of controls to which fresh culture medium was added. After $3 \mathrm{~h}$, the cells were gently trypsinized (trypsin/ PBS $^{-}$1:1 v/v) and resuspended in fresh medium. The samples were centrifuged $(200 \mathrm{~g}$ for $2 \mathrm{~min}$ ) and the pellets resuspended in $\mathrm{PBS}^{-}(1 \mathrm{ml})$. Aliquots $(10 \mu \mathrm{l})$ of JC-1 $\left(5,5^{\prime}, 6,6^{\prime}\right.$ tetrachloro-1,1',3,3'-tetraethylbenzimidazolcarbocyanine iodide) dye $(200 \mu \mathrm{M})$ were added to each sample. Cells not treated with peptide exposed to $2 \mu \mathrm{l}$ of CCCP (carbonyl cyanide 3-chlorophenylhydrazone) were used as a positive control; CCCP strongly lowers the mitochondrial transmembrane potential. The samples were incubated for $15 \mathrm{~min}$ in a standard $37^{\circ} \mathrm{C}$ incubator. Next, the cells were centrifuged $(200 \mathrm{~g}, 2 \mathrm{~min})$, the samples were washed $\left(2 \mathrm{ml} \mathrm{PBS}^{-}\right)$, resuspended $\left(0.5 \mathrm{ml} \mathrm{PBS}^{-}\right)$and analyzed by flow cytometry (FACS Canto instrument). In living cells having high mitochondrial potential the JC-1 dye forms complexes emitting red fluorescence. In turn, dead cells are characterized by low mitochondrial potential. In such cells the JC-1 dye remains in monomeric state emitting green fluorescence. The percentage change of transmembrane potential was calculated ( $v$ s control set at 100\%).

\section{ATP Determination}

B16-F10 cells were seeded $\left(5 \times 10^{5}\right.$ cells $/ 3 \mathrm{ml}$ medium/well in six-well plates (NUNCLON Surface, NUNC) and cultured for $24 \mathrm{~h}$. The growth medium was then replaced with medium containing CAMEL $(2-10 \mu \mathrm{M})$. Fresh growth medium without peptide was used for controls. At the conclusion of incubation with CAMEL (30-180 $\mathrm{min})$, the cells were trypsinized $\left(0.4 \mathrm{ml} / 3 \mathrm{~min}\right.$, trypsin/ $\left./ \mathrm{PBS}^{-} 1: 1 \mathrm{v} / \mathrm{v}\right)$ and resuspended in fresh medium. The samples were centrifuged $(200 \mathrm{~g}$ for $2 \mathrm{~min}$ ) and cell pellets resuspended in $1 \mathrm{ml} \mathrm{PBS}^{-}$and centrifuged again. The cells were recovered from the pellets and resuspended in $1 \mathrm{ml}$ of lysis buffer (Promega), shaken for $10 \mathrm{~s}$ and centrifuged again ( $400 \mathrm{~g}$ for $1 \mathrm{~min}$ ). The supernatant was collected, diluted 40 -fold and $10 \mu \mathrm{l}$ of the dilution was added to Standard Reaction Solution $(90 \mu \mathrm{l})$ from the ATP Determination Kit (Invitrogen Molecular Probes). Oxyluciferin concentration was determined after measuring luminescence using a Lumat LB 9501 luminometer (Berthold). The protein content was assayed by Bradford method and sample luminescence was expressed as RLU/mg of protein. Data from three separate measurements were used to calculate average values.

\section{Electron Microscopy of CAMEL-Treated Cell Cultures}

B16-F10 cells were seeded $\left(5 \times 10^{5}\right.$ cells $/ 3 \mathrm{ml}$ RPMI-1640 medium with $10 \%$ serum/well) in six-well plates
(NUNCLON Surface, NUNC) and grown for $24 \mathrm{~h}$. Growth medium was then replaced with medium containing CAMEL $(5 \mu \mathrm{M})$, with controls receiving fresh growth medium. At the conclusion of incubation with CAMEL (30-180 min), the cells were trypsinized $\left(0.3 \mathrm{ml} / 3 \mathrm{~min}\right.$, trypsin/PBS $\left.{ }^{-} 1: 1 \mathrm{v} / \mathrm{v}\right)$ and resuspended in fresh medium. The samples were centrifuged ( $200 \mathrm{~g}$ for $5 \mathrm{~min}$ ) and the cells were prepared for transmission electron microscopy according to a standard method, ${ }^{11}$ with minor variations. In brief, cells were recovered from the pellet after a 5-min centrifugation at $200 \mathrm{~g}$. Subsequently, the cells were fixed overnight at $4{ }^{\circ} \mathrm{C}(3 \%$ glutaraldehyde in $0.1 \mathrm{M}$ phosphate buffer $\mathrm{pH} 7.4)$. The fixative was then removed and cells were washed and mounted in warm $\left(45^{\circ} \mathrm{C}\right) 2 \%$ agar solution. After polymerization, the agar-mounted specimens were cut into small cubes. The specimens were postfixed at $4{ }^{\circ} \mathrm{C}\left(2 \mathrm{~h}, 1 \% \mathrm{O}_{\mathrm{S}} \mathrm{O}_{4}\right)$, dehydrated in graded ethanol, submerged in propylene oxide and embedded in Epon 812 resin. The ultrathin sections were mounted on 300 mesh grids, stained with uranyl acetate and lead citrate and examined using JOEL JEM-100 CX transmission electron microscope at $80 \mathrm{kV}$.

\section{Caspase 3 Determination after CAMEL Treatment}

HL-60 cells were seeded $\left(5 \times 10^{5}\right.$ cells $/ 3 \mathrm{ml}$ medium/well in six-well plates (NUNCLON Surface, NUNC) and cultured for $24 \mathrm{~h}$. The growth medium was replaced with medium containing CAMEL (5 and $10 \mu \mathrm{M})$. Fresh growth medium without peptide was added to controls. Cells treated with camptothecin solution $(6 \mu \mathrm{M})$ were used as positive controls. After incubation $(4 \mathrm{~h})$ in the presence of CAMEL the cells were trypsinized $\left(0.4 \mathrm{ml} / 3 \mathrm{~min}\right.$, trypsin/PBS $\left.{ }^{-} 1: 1 \mathrm{v} / \mathrm{v}\right)$ and resuspended in fresh medium. The samples were centrifuged at $200 \mathrm{~g}$ for $2 \mathrm{~min}$ and cell pellet resuspended in $1 \mathrm{ml} \mathrm{PBS}$ and centrifuged again. The cells were then resuspended in $\mathrm{BD}$ Cytofix/Cytoperm and washed twice with BD Perm/Wash buffer. The cells were further incubated on ice $(20 \mathrm{~min})$. Next, the cells were resuspended in Perm/Wash buffer with antibody against active caspase 3 and incubated for $30 \mathrm{~min}$ at RT. The cells were then washed in Perm/Wash buffer and analyzed by flow cytometry (FACS Canto instrument).

\section{Therapy of Murine Melanoma Tumor-Bearing Mice with CAMEL}

C57BL/6 female mice (6-8 weeks old), bred and maintained in own animal facility, were used throughout the study. Permission from the local ethical committee of the Medical University of Silesia was obtained for all experiments. At 6 days after inoculation of mice with B16-F10 cells, when tumors reached ca. $5 \mathrm{~mm}$ in diameter, the mice were given intratumoral injections of a previously optimized dose of CAMEL or control peptide (YGWVLNESTILIFPK) $(115 \mu \mathrm{g}$ peptide $/ 100 \mu \mathrm{lBS}^{-} /$animal) or $100 \mu \mathrm{lPBS}^{-}$. CAMEL peptide was also administered intravenously (at 115 or $200 \mu \mathrm{g}$ peptide $/ 400 \mu \mathrm{lBS}^{-}$per animal). A total of three injections were performed. Each treatment group consisted of five mice. 
The effectiveness of therapy was monitored and determined based on measurable reduction of tumor growth rate.

In subsequent therapeutic experiments the mice were given intratumoral injections of higher dose of CAMEL $(250 \mu \mathrm{g}$ peptide $/ 100 \mu \mathrm{l} \mathrm{PBS}^{-}$per animal). The peptide was administered daily for 5 consecutive days and then the therapy was interrupted for 5 days. When tumors resumed growth the sequence of CAMEL injections (as above) was repeated. In total, three such CAMEL sessions were completed. Animals from control groups received $100 \mu \mathrm{l}$ of $\mathrm{PBS}^{-}$. Each treatment group consisted of five mice. The effectiveness of therapy was monitored and determined based on measurable reduction of tumor growth rate and prolongation of survival.

\section{Immunohistochemical Analyses}

C57BL/6 mice were inoculated intradermally (dorsal side) with $2 \times 10^{5}$ B16-F10 murine melanoma cells. When tumors reached ca. $5 \mathrm{~mm}$ in diameter, the mice received intratumorally two injections of CAMEL alone $(115 \mu \mathrm{g} / 100 \mu \mathrm{l}$ $\mathrm{PBS}^{-}$) or CAMEL followed by nine injections of plasmid DNA carrying IL-12 gene $(50 \mu \mathrm{g} / 100 \mu \mathrm{l})$. At $24 \mathrm{~h}$ after conclusion of injections, the tumors were excised, fixed in $2 \%$ paraformaldehyde ( $\mathrm{pH}$ 7.2) and paraffin embedded. The tumors were then sectioned into 5-6- $\mu \mathrm{m}$ thick slices. The specimens were stained by hematoxylin and eosin (H\&E). Necrotic areas were visualized using a Nikon 80i microscope. A similar experiment was performed using mice harboring 4T1 mammary carcinoma tumors. BALB/c mice were injected 4T1 cells $\left(1 \times 10^{5}\right)$ and administered CAMEL (doses as indicated above) starting from day 6 after inoculation. Tumor sections were also incubated for $1 \mathrm{~h}$ with anti-HMGB1 rabbit antibody (Abcam) at 1:200 dilution. The unbound antibody was removed by rinsing the sections with $\mathrm{PBS}^{-}$. Horseradish peroxidase-conjugated anti-rabbit IgG (Vector Laboratories) was used as secondary antibody $(1 \mu \mathrm{g} / \mathrm{ml}, 30 \mathrm{~min})$. After rinsing with $\mathrm{PBS}^{-}$the sections were incubated with $\mathrm{DAB}$. To visualize tumor structure the sections were stained with hematoxylin solution. Micrographs were taken and analyzed using Lucia software.

\section{CAMEL and IL-12 Gene in Combination Therapy of Mice Bearing Experimental Melanoma Tumors}

At 6 days after inoculation with tumor cells, C57BL/6 strain mice bearing experimental B16-F10 melanoma tumors were injected intratumorally with CAMEL $\left(115 \mu \mathrm{g} / 100 \mu \mathrm{l} \mathrm{PBS}^{-}\right.$ per animal). The peptide was administered to mice on 2 consecutive days. Next, the animals received intratumoral injections of BCMGSNeo plasmid DNA $(50 \mu \mathrm{g}$ in $100 \mu \mathrm{l}$ $\mathrm{PBS}^{-}$) containing murine IL-12 gene. ${ }^{12}$ DNA administration was continued daily for 14 days. After a 5-day pause the animals were again treated with CAMEL (three injections of $115 \mu \mathrm{g}$ peptide in $100 \mu \mathrm{l} \mathrm{PBS}^{-}$). Finally, another round of administration of plasmid DNA with IL-12 gene $(50 \mu \mathrm{g}$ in $100 \mu \mathrm{lBS}^{-}$for 14 consecutive days) was completed. Control mice received either plasmid DNA, or CAMEL or $\mathrm{PBS}^{-}$only.
Each treatment group consisted of five mice. Effectiveness of therapy was judged again in terms of measurable reduction in tumor growth rate and extension of animal survival.

\section{Statistical Analysis}

Student's $t$-test was performed to analyze tumor growth kinetics. Differences in the survival time of tumor-bearing animals were analyzed using the log-rank test. The results were deemed significant when $P<0.05$.

\section{RESULTS}

\section{CAMEL is Cytotoxic for Tested Cell Lines}

Increasing the amount of CAMEL $(1-20 \mu \mathrm{M})$ proved toxic to all tested cell lines The $\mathrm{LC}_{50}$ values were from 2.95 to $5.2 \mu \mathrm{M}$ for normal cells (HECa10, HEC PP, NIH3T3, Wi38) and $1.75 \mu \mathrm{M}$ for B16-F10 melanotic cell line, $1.3 \mu \mathrm{M}$ for RENCA, $4.1 \mu \mathrm{M}$ for WM1158 and 6.2 for $4 \mathrm{~T} 1$ cells (Figure 1). Control peptide was not toxic to B16-F10 cell line even at $50 \mu \mathrm{M}$ concentration.

\section{CAMEL does not Cause Erythrocyte Hemolysis}

Fresh blood drawn from C57BL/6 mice was incubated with CAMEL $(1-100 \mu \mathrm{M})$ for either $30 \mathrm{~min}, 2 \mathrm{~h}$ or $24 \mathrm{~h}$. Under these conditions no significant change in the number of cells was observed, indicating lack of lysis. In addition, CAMEL administration was associated with insignificant increase in hemolysis. At peptide concentrations up to $10 \mu \mathrm{M}$, no changes could be shown compared with cells not treated with CAMEL. At $20 \mu \mathrm{M}$ peptide the extent of hemolysis was increased by $5 \%$, whereas at $40 \mu \mathrm{M}$ the percentage of lysed cells was $17 \%$, and reached $30 \%$ at $100 \mu \mathrm{M}$ CAMEL (Figure 2). Thus, even at highest CAMEL concentration tested it did not cause the lysis of more than half of erythrocytes present. As positive control, $1 \%$ Triton X-100 in water was used; under normal conditions, this treatment results in complete lysis of red blood cells. At CAMEL concentrations toxic for B16-F10 cells the peptide did not cause erythrocyte hemolysis.

In another experiment the $\mathrm{LDH}$ release from B16-F10 murine melanoma cells was analyzed. After CAMEL administration (at 2 or $5 \mu \mathrm{M}$ ), even after a 2-h incubation no significant differences were observed in the amount of $\mathrm{LDH}$ released. However, CAMEL administration at $10 \mu \mathrm{M}$ did increase the amount of released LDH by $40 \%$ vs control after a 10-min incubation (data not shown).

\section{CAMEL Localizes in Mitochondria}

Isolated mitochondria were incubated with FITC-conjugated CAMEL peptide and MitoTracker Red solution. Flow cytometry analysis has shown that both red fluorescence of MitoTracker and green fluorescence of CAMEL colocalized in the same structures, that is, mitochondria (Figure 3b, d and $\mathrm{f}$ ). Control not treated with CAMEL is shown in Figure 3a, $c$ and e.

CAMEL did not cause destruction of cell membranes as indicated by the lack of red staining of cell nucleus when 


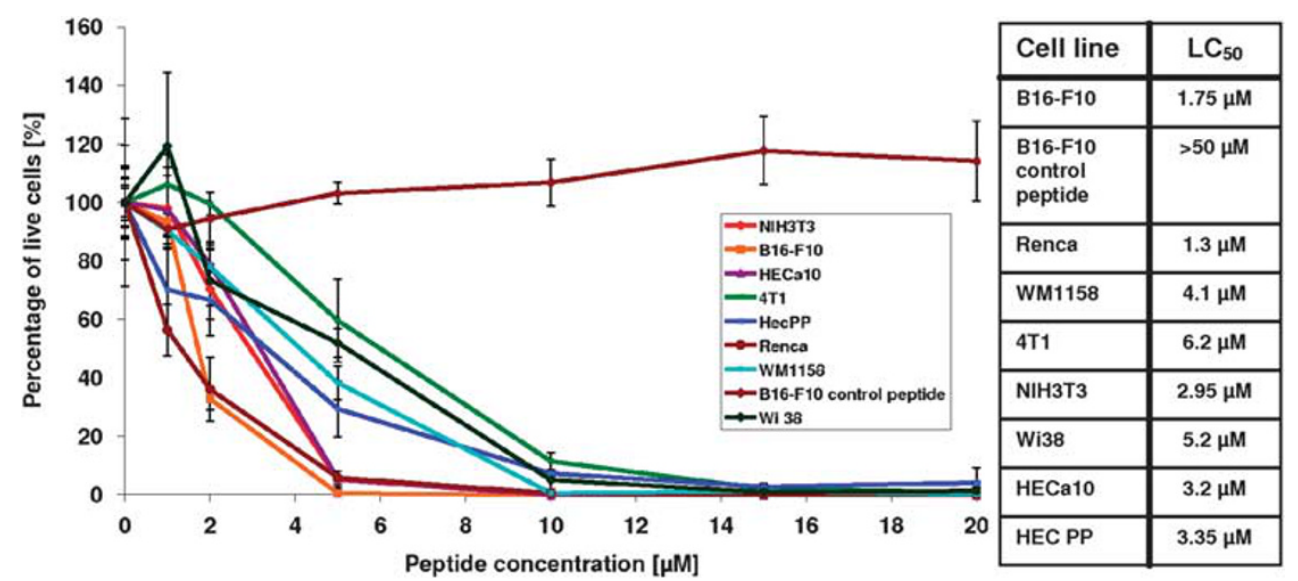

Figure 1 Dose-dependent effects of CAMEL on cultured cells of selected cell lines. Murine melanoma cells (B16-F10), renal cancer cell (RENCA), mammary carcinoma (4T1), human melanoma (WM1158), murine fibroblasts (NIH3T3), human fibroblasts (Wi38) and mouse endothelial cells (HECa10 and HEC PP) were incubated overnight with increasing doses of CAMEL $(0-20 \mu \mathrm{M})$ and cell survival was determined by MTT test. The table shows $L C_{50}$ for individual cell lines.

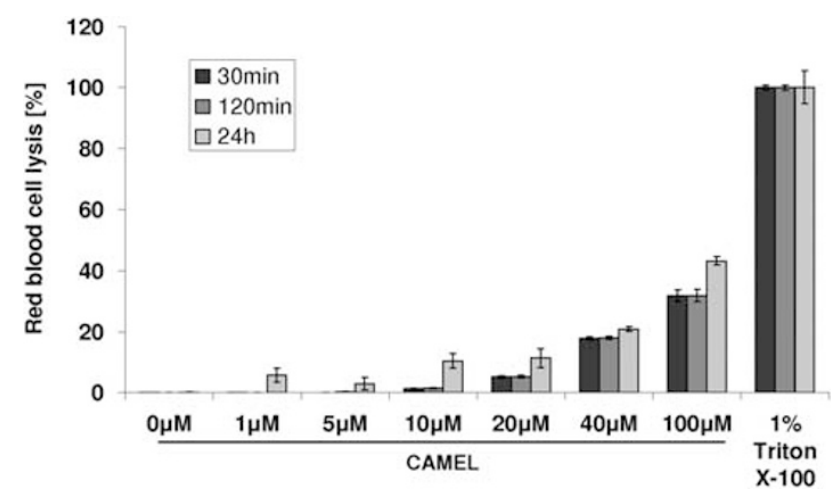

Figure 2 Effects of CAMEL on erythrocyte lysis. Blood was collected from mice (C57BL/6 strain). A 10\% erythrocyte suspension in Triton X-100 solution was incubated with increasing doses of CAMEL (1-100 $\mu \mathrm{M})$. Negative control: $\mathrm{PBS}^{-}$alone; positive control: $1 \%$ Triton $\mathrm{X}-100$ aqueous solution. After $30 \mathrm{~min}, 120 \mathrm{~min}$ and $24 \mathrm{~h}$ of incubation, sample absorbance was read at $\lambda=405 \mathrm{~nm}$. On the basis of these readings, the percentage of erythrocytes undergoing CAMEL-induced lysis was determined.

propidium iodide is present. FITC-labeled CAMEL (green), upon addition to B16-F10 murine melanoma-cultured cells, localizes inside cells after an incubation lasting for a few minutes only. With time, an increasing number of cells showed CAMEL accumulation in the cytoplasm. CAMEL did not localize in cell nucleus. Subsequent cell swelling and rupture of the plasma membrane caused dead cell nuclei to stain red with PI. The number of dead cells increased as time elapsed (see Supplementary data).

\section{CAMEL Causes Decrease in Mitochondrial Transmembrane Potential}

Treatment with CAMEL caused a significant drop in mitochondrial membrane potential (directly dependent on peptide dose). At $2 \mu \mathrm{M}$, CAMEL caused the potential to drop to $75 \%$ (untreated control $=100 \%$ ); at $5 \mu \mathrm{M}$ the potential dropped to $38.5 \%$ whereas at $10 \mu \mathrm{M}$ the drop reached $29 \%$ of the control value (Figure 4). As positive control, a CCCP solution was used; this compound totally abolishes mitochondrial membrane potential in cells.

\section{CAMEL Causes Drop in Cellular ATP Level}

ATP content was determined in cell lysates obtained from B16-F10 murine melanoma cells that were treated for $30-180$ min with increasing amounts of CAMEL $(2-10 \mu \mathrm{M})$. Addition of $2 \mu \mathrm{M}$ CAMEL lowered within $180 \mathrm{~min}$ the ATP content by $40 \%$ when compared with control. Further increase of CAMEL concentration $(5 \mu \mathrm{M})$ brought down the content of ATP to $30 \%$, and, at $10 \mu \mathrm{M}$, to $<20 \%$ (Figure 5).

\section{CAMEL Causes Swelling of Mitochondria}

Transmission electron microscopy (Figure 5) of B16-F10 murine melanoma cells treated with CAMEL $(5 \mu \mathrm{M})$ show noticeable cell swelling after only a 30-min incubation in the peptide-containing medium. The swelling increased progressively from 30 to $180 \mathrm{~min}$. Insets in Figure 6 micrographs show swelling of single mitochondria.

\section{CAMEL does not Activate Caspase 3}

The level of caspase 3 after CAMEL treatment was determined. At 5 and $10 \mu \mathrm{M}$ concentrations, CAMEL did not activate caspase 3 within cells (Figure 7). Caspase 3 was active in 7.1 and $5 \%$ of the cells examined, respectively. As positive control, camptothecin $(6 \mu \mathrm{M})$-treated cells were used; approximately $50 \%$ of these cells have activated caspase 3 and cells with active caspase 3 accounted for $8.6 \%$ of them.

\section{CAMEL Inhibits Growth of B16-F10 Murine Melanoma Tumors}

After intratumoral administration, CAMEL inhibited growth of B16-F10 tumors. Even single CAMEL dose led to significant tumor shrinkage within $24 \mathrm{~h}$. No similar effect has 
a

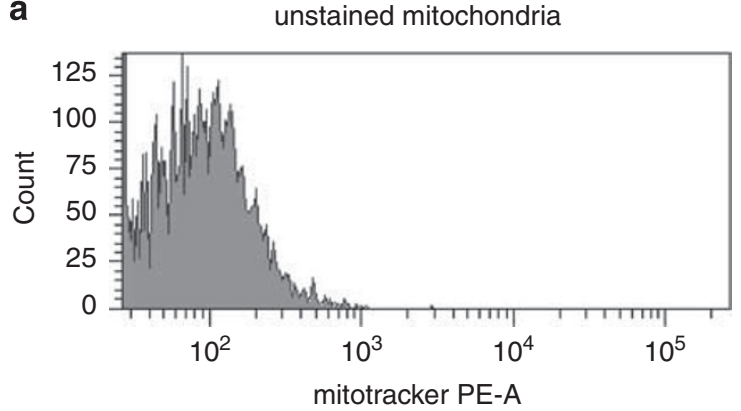

C

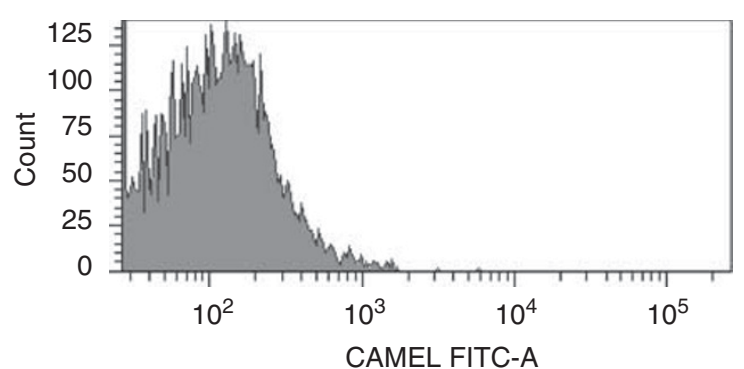

e

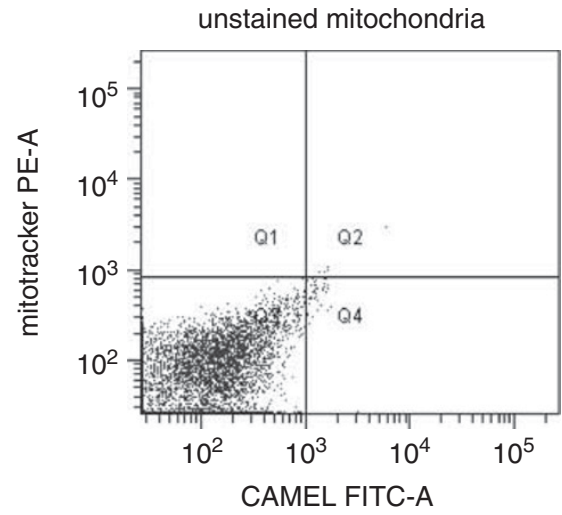

b

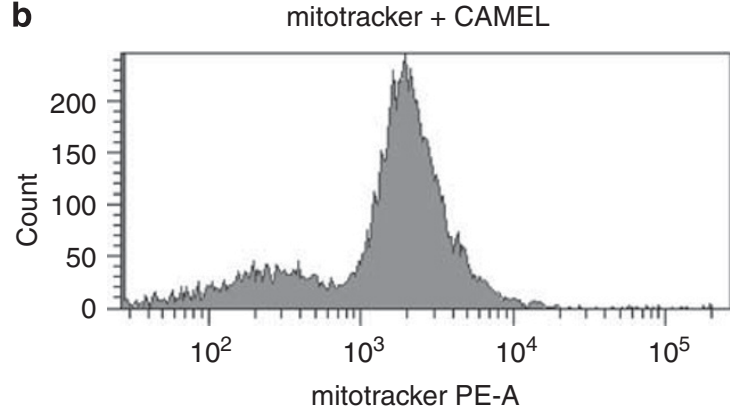

d

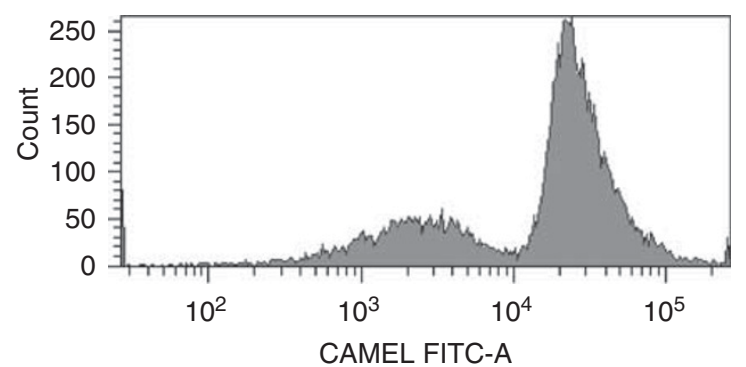

$\mathbf{f}$

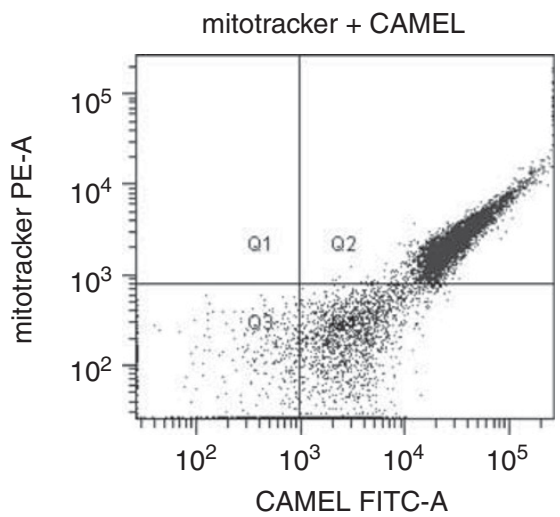

Figure 3 CAMEL localizes in mitochondria. Isolated mitochondria were treated with CAMEL-FITC peptide solution ( $5 \mu \mathrm{M})$ and with MitoTracker Red $(500 \mathrm{nM})$. After a 10-min incubation the mitochondria were analyzed using flow cytometry. Flow cytometry analysis has shown that both red fluorescence of MitoTracker (b) and green fluorescence of CAMEL (d) colocalized in the same structures, that is, mitochondria (f). Neither control (mitochondria not treated with CAMEL) nor mitochondria treated with MitoTracker showed any fluorescence (a, $\mathbf{c}$ and $\mathbf{e})$.

been observed after injection of control peptide (Figure 8). Tumor volumes in the groups receiving PBS and control peptide, when compared with the group receiving CAMEL, were significantly larger starting from day 9 of therapy $(P<0.05)$, and reaching $P=0.046$ on day 16 . Tumor growth was inhibited as long as administrations of CAMEL continued. If, however, the peptide-mediated therapy was interrupted, increased tumor volumes were noticeable after a couple of days.

CAMEL was also administered intravenously (at 115 or $200 \mu \mathrm{g}$ doses). After 13 days of therapy with $115 \mu \mathrm{g}$ CAMEL, tumor growth was inhibited by 59\% (compared with $96 \%$ in case of intratumoral administration). At $200 \mu \mathrm{g}$ CAMEL the intravenous administration yielded a $76 \%$ growth inhibition (data not shown). Thus, therapeutic efficacy of intravenous administration did not match the intratumoral one.

To highlight the therapeutic potential of CAMEL, another sequence of its administration was used. First, mice received intratumoral injections of CAMEL $\left(250 \mu \mathrm{g} / 100 \mu \mathrm{l} \mathrm{PBS}^{-}\right)$for 5 consecutive days. The administrations were then discontinued and resumed after 5 days, when tumors had started growing again. In total, three such sequential sessions were accomplished. As a result, a significant inhibition of tumor growth was observed (Figure 9). Again, tumor growth was restricted as long as CAMEL injections were continued. Tumor volume differences between the control group $v s$ the CAMEL-receiving group were statistically significant from day 7 of therapy $(P<0.05)$, and reaching $P=0.0059$ on day 18. After three consecutive series of peptide intratumoral 


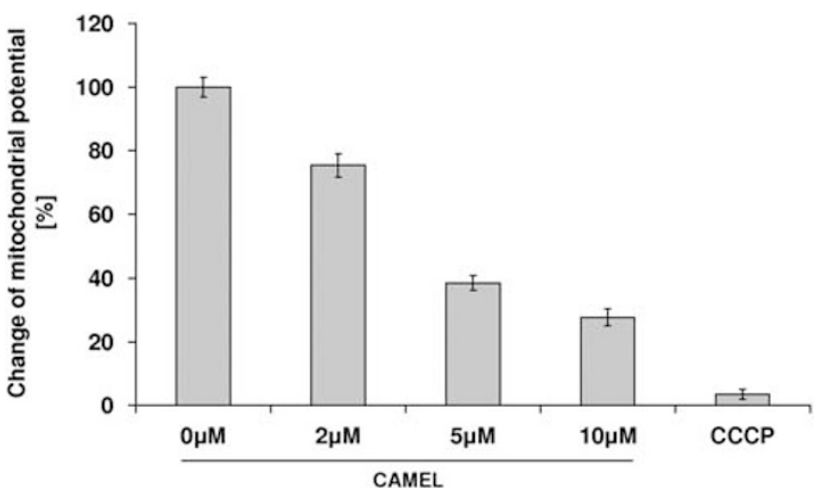

Figure 4 Effects of CAMEL on mitochondrial potential. Murine melanoma B16-F10 cell cultures were incubated with CAMEL $(2,5$ and $10 \mu \mathrm{M})$ for $3 \mathrm{~h}$. The cells were collected, JC1 (Invitrogen) was added and the samples were analyzed by flow cytometry. As positive control, cells incubated with CCCP (totally abolishes mitochondrial gradient) solution were used. The drop in mitochondrial potential was calculated with peptide non-treated group used as a control.

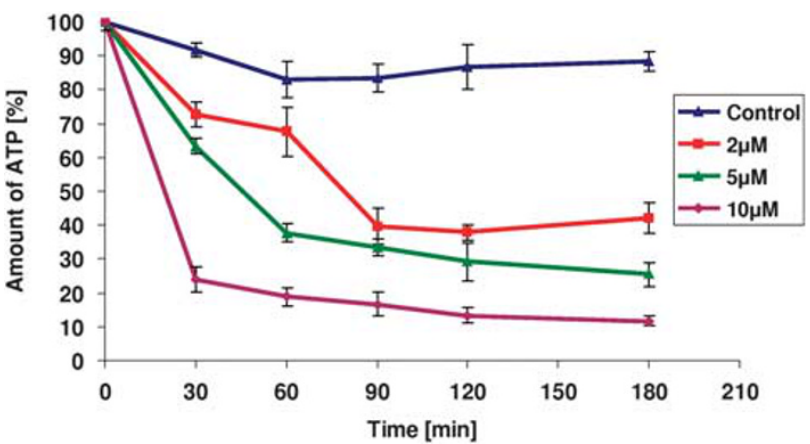

Figure 5 Determination of ATP level in CAMEL-treated cultured cells. B16F10 murine melanoma cultures were incubated in RPMI-1640 medium supplemented with $10 \%$ serum and containing varying amounts of CAMEL $(2-10 \mu \mathrm{M})$. At the end of incubation period (30-180 $\mathrm{min})$ the cells were lysed. Aliquots $(10 \mu \mathrm{l})$ of lysates were added to a reaction mix containing D-luciferin and luciferase and sample luminescence was read using a luminometer. All samples also had their protein content measured. Relative amounts of ATP were calculated as extent of luminescence (RLU) per mg of protein. The graph shows percentage of ATP in cells after CAMEL administration. Cells that were not treated with CAMEL were considered as containing $100 \%$ ATP.

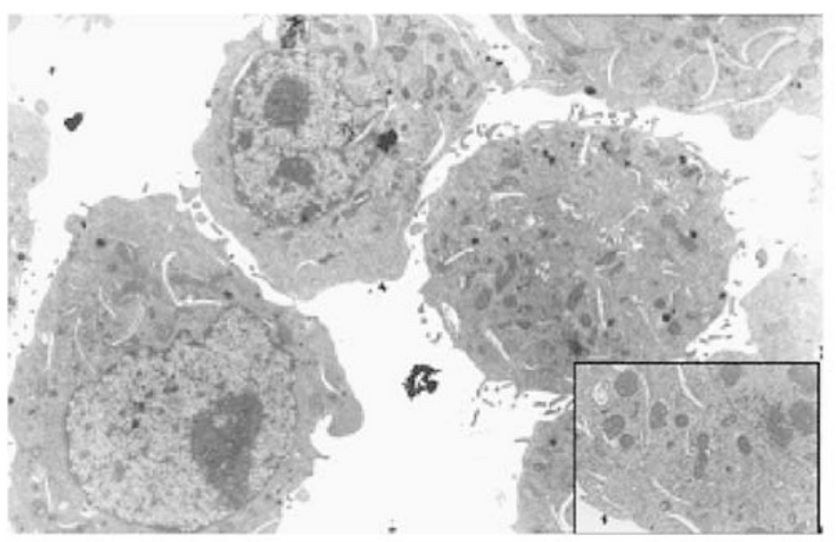

Oh

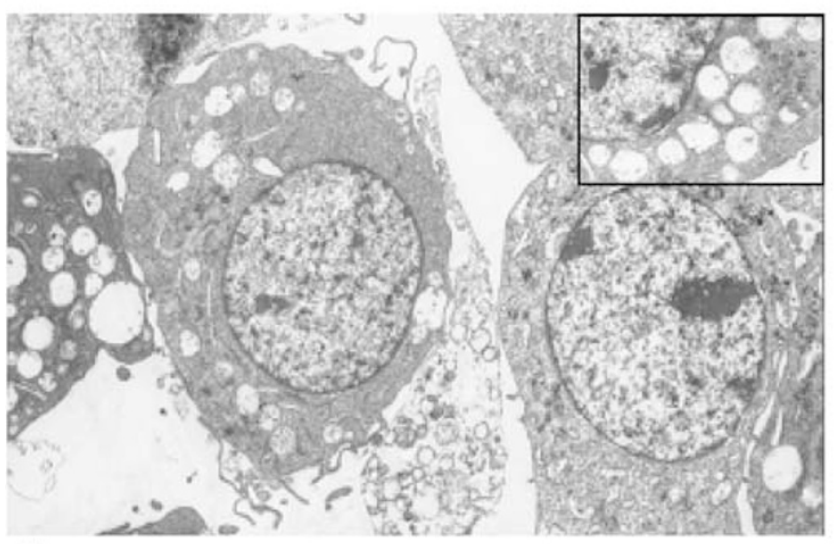

1h

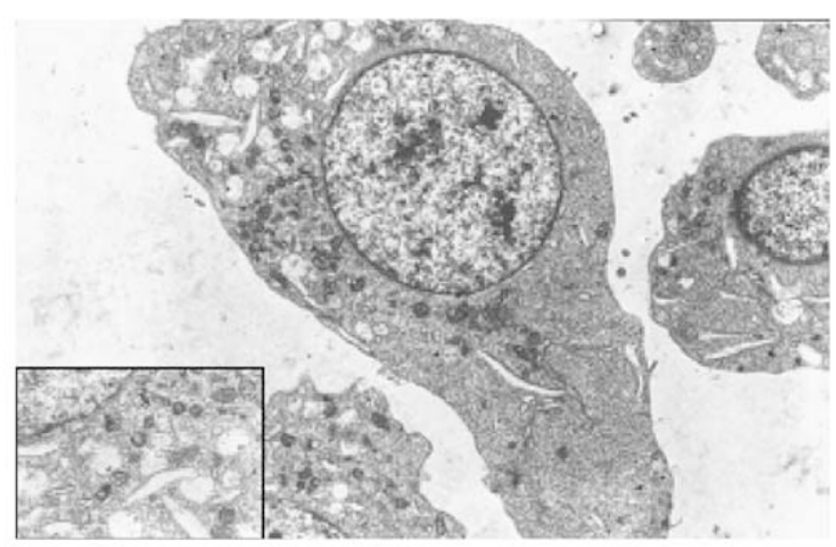

$0.5 \mathrm{~h}$

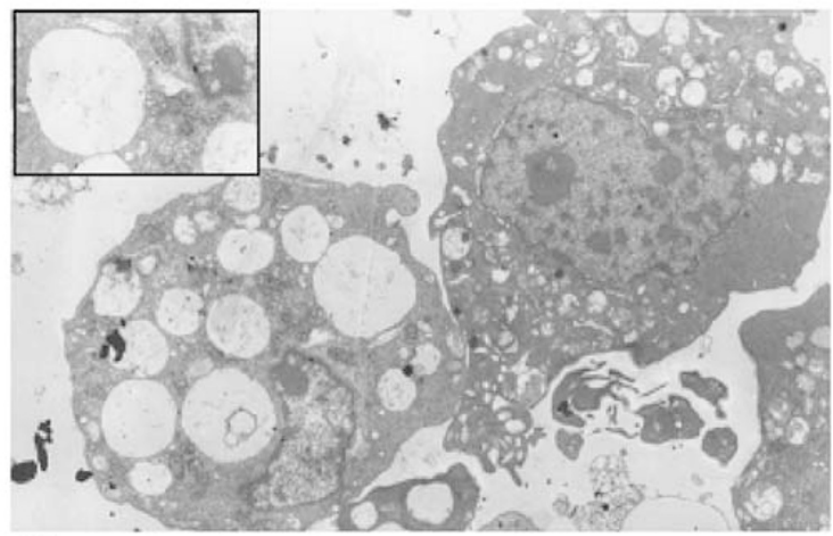

$3 h$

Figure 6 Effects of CAMEL on mitochondrial ultrastructure. B16-F10 murine melanoma cultures were incubated in RPMI-1640 medium supplemented with $10 \%$ serum and CAMEL $(5 \mu \mathrm{M})$. At the end of incubation period $(0-3 \mathrm{~h})$ cells were fixed with glutaraldehyde and the preparations were processed to enable electron microscopic observation. The pictures show cells with enlarged mitochondria (magnification $\times 2600$ ). Insets show single mitochondria. Note the considerable swelling (magnification $\times 10000)$. 

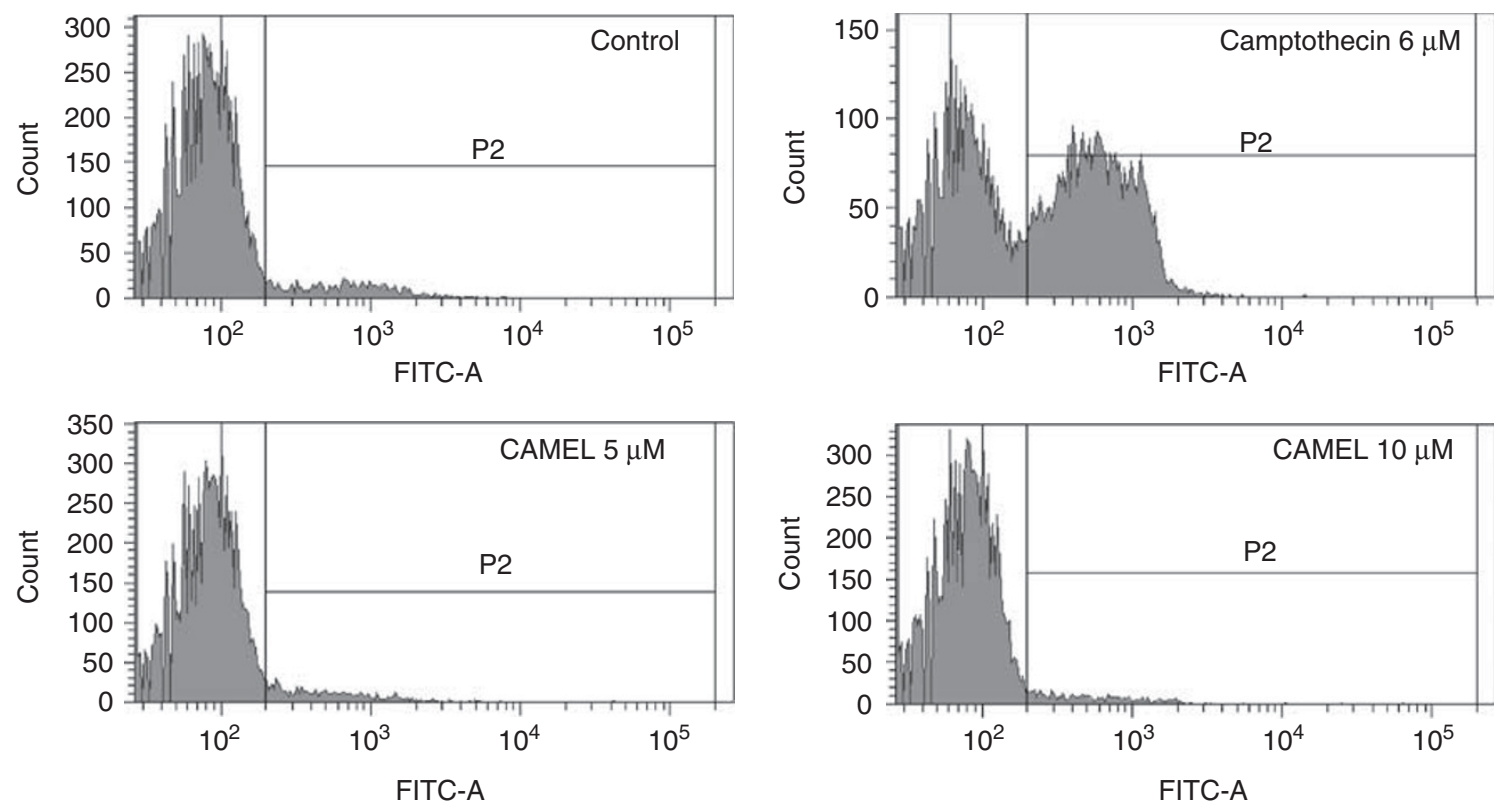

\begin{tabular}{l|c} 
& Caspase-3 positive cells [\%] \\
\hline Control & 8.6 \\
\hline Camptothecin $6 \mu \mathrm{M}$ & 50.6 \\
\hline CAMEL $5 \mu \mathrm{M}$ & 7.1 \\
\hline CAMEL $10 \mu \mathrm{M}$ & 5.0
\end{tabular}

Figure 7 Determination of caspase-3 activation in CAMEL-treated cultured cells. Human promyelocytic leukemia cells (HL-60) were incubated with CAMEL $(5$ or $10 \mu \mathrm{M}$ ) for $4 \mathrm{~h}$. The cells were collected and antibody (BD Pharmingen) against active caspase 3 was added. The samples were analyzed using flow cytometry. Cells incubated with camptothecin $(6 \mu \mathrm{M})$ made up positive control.

application, significant extension of animal survival was also observed $(P=0.021)$. Tumor-bearing mice treated with CAMEL lived longer and in $20 \%$ of cases tumor regression was complete.

\section{CAMEL Causes Tumor Necrosis, Restricts Tumor Growth and Triggers HMGB1 Protein Release from Cells}

Mice bearing B16-F10 melanoma tumors ca. $5 \mathrm{~mm}$ in diameter were given intratumoral injections of CAMEL $\left(115 \mu \mathrm{g} / 100 \mu \mathrm{l} \mathrm{PBS}^{-}\right.$per animal) for 4 consecutive days. As a result, tumor volumes were decreased compared with control $\left(\mathrm{PBS}^{-}\right)$(Figure 10a and b).

Histochemical specimens were prepared using tumor material from either non-treated (single dose of $\mathrm{PBS}^{-}$) or treated (single dose of CAMEL, $115 \mu \mathrm{g} / 100 \mu \mathrm{l} \mathrm{PBS}^{-}$) animals. The specimens were stained with H\&E. Microscopic examination of melanoma B16-F10 sections clearly revealed blood vessels and neoplastic cells surrounding them
(Figure 10c, control). However, sections prepared from tumors injected with CAMEL show large necrotic areas, together with numerous regions corresponding to extravasated blood (Figure 10d). The same effect of CAMEL administration was observed in sections obtained from murine mammary carcinoma tumors (data not shown).

To visualize the presence of HMGB1 cytokine (a necrotic marker) in the extracellular environment, sections prepared from murine melanoma tumors injected with CAMEL $(115 \mu \mathrm{g}$ per animal) were treated with an anti-HMGB1 antibody. The control sections revealed HMGB1 (stained brown) to be present mainly in cell nuclei (Figure 10e), and also in the cytoplasm and outside of the cells. However, sections obtained from tumors treated with CAMEL revealed mainly cytoplasmic and extracellular HMGB1 presence, whereas minimal amount of brown staining was detected in nuclei, with the latter mostly stained with hematoxylin (Figure 10f). 


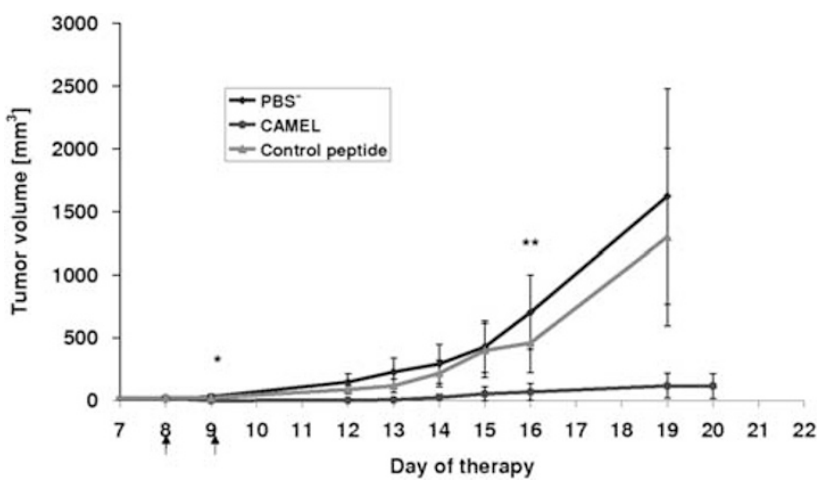

Figure 8 Effects of therapy with CAMEL on murine melanoma growth. At 6 days after inoculating C57BL/ 6 strain mice with B16-F10 cells, when tumors reached ca. $5 \mathrm{~mm}$ in diameter, the mice were given intratumoral injections $\left(115 \mu \mathrm{g} / 100 \mu \mathrm{l} \mathrm{PBS}^{-}\right)$of CAMEL or control peptide (YGWVLNESTILIFPK) or PBS $^{-}$alone. The peptide was administered daily on 2 days. Each treatment group consisted of five mice. Effectiveness of therapy was monitored and determined based on reduction of tumor growth rate. Differences in tumor volume between the group receiving $\mathrm{PBS}^{-}$or control peptide vs the group receiving CAMEL was statistically significant starting from day 9 of therapy $\left({ }^{*} P<0.05\right)$, and reaching ${ }^{* *} P=0.046$ on day 16 .

\section{Combination of CAMEL and Plasmid DNA Carrying IL-12 Gene Inhibits Growth of B16-F10 Murine Melanoma Tumors}

Melanoma tumor-bearing mice received intratumoral injections of CAMEL $\left(115 \mu \mathrm{g} / 1 \mathrm{ml} \mathrm{PBS}^{-}\right)$for 2 consecutive days. For the next 14 days, the animals were injected intratumorally daily with BCMGSNeo plasmid DNA (50 $\mu \mathrm{g} /$ $100 \mu \mathrm{l}$ per animal) carrying the murine IL-12 gene. Upon completion of this protocol and an additional 5-day pause, the mice were treated again with three injections of CAMEL and then, for 14 days, again with the plasmid DNA. After the first round of CAMEL administrations, a significant tumor shrinkage was observed. However, during the subsequent period of plasmid DNA injections, tumors started regrowing. The mice were then subjected to the second round of CAMEL administrations and then to injections of plasmid DNA carrying the IL-12 gene. This strategy led to a significant reduction in tumor volumes compared with controls (mice treated with $\mathrm{PBS}^{-}$, CAMEL only, or plasmid DNA only; see Figure 11). The difference between tumor volumes in the group receiving CAMEL and in the group receiving both CAMEL and plasmid DNA with IL-12 gene was statistically significant from day 13 of therapy $(P<0.05)$, and reaching $P=0.02$ on day 19 .

Applying the above-described alternating mode of peptide/ plasmid administrations also resulted in a statistically significant extension of survival $(P=0.018)$. The animals treated with CAMEL and IL-12-gene-carrying plasmid lived significantly longer than control. The therapy with two series of CAMEL and plasmid DNA administrations yielded complete tumor regression in $60 \%$ of animals.

$\mathrm{H} \& \mathrm{E}$ staining of tumor sections obtained from mice treated with CAMEL revealed that blood vessels were enlarged (red arrows). On the other hand, in tumors treated

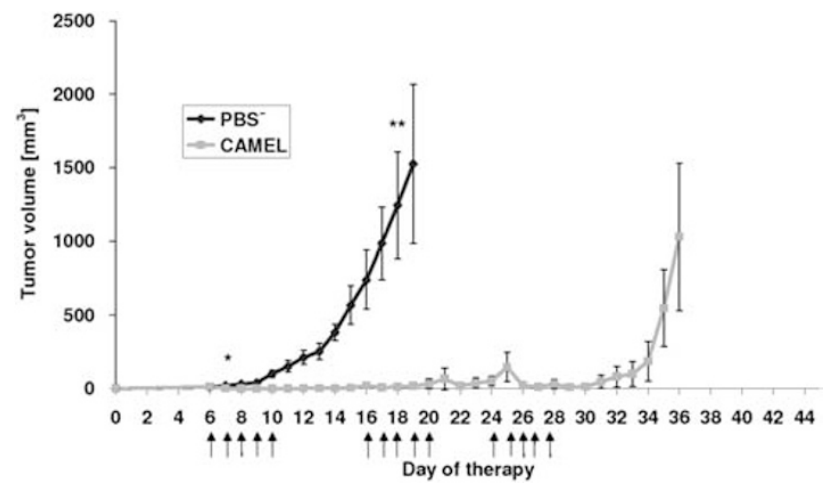

Figure 9 Effects of therapy with CAMEL on murine melanoma growthrepeated administration series. Intratumoral CAMEL injections $(250 \mu \mathrm{g} /$ $100 \mu$ PBS $^{-}$) were started on day 6 after inoculation of mice with B16-F10 cells, when tumors reached ca. $0.5 \mathrm{~mm}$ in diameter. The peptide was administered daily for 5 consecutive days, followed by a 5-day repose. When tumors started regrowing, therapy with CAMEL was resumed (next five injections, as above). In total, three sessions were completed. Each of the treatment groups had five animals. Graph shows the effect of peptide on tumor growth (arrows indicate peptide administration). The difference between tumor volume between the control group and the CAMELreceiving group was statistically significant from day 7 of therapy $\left({ }^{*} P<0.05\right)$ and reaching ${ }^{*} P=0.0059$ on day 18 .

with CAMEL and plasmid DNA carrying IL-12 gene no such enlargement was found. In both cases leukocyte infiltration was present (blue arrows; Figure 12).

\section{DISCUSSION}

A number of naturally occurring antibacterial peptides show anticancer activity. As they are relatively easy to obtain and modify and show considerable therapeutic efficacy, such peptides are considered promising agents for novel anticancer therapies. Some of these peptides destroy neoplastic cells by disrupting their cell membrane whereas others cause destruction of mitochondrial membranes. ${ }^{1}$

The compound CAMEL is a synthetic hybrid peptide, made up from cecropin A and melittin. ${ }^{7}$ It seemed justified to test CAMEL in anticancer therapy as this peptide is capable of destroying cellular membranes, and mitochondrial membrane is believed to originate from endosymbiotic prokaryotes. We studied the mechanism of CAMEL effectiveness against cancer cells. We also evaluated the peptide's efficacy in the treatment of experimental melanoma tumors in mice, both singly and in combination with interleukin-12encoding plasmid DNA, an immune-stimulating drug.

Compared with different antimicrobial substances showing anticancer properties, such as citropine $\left(\mathrm{LC}_{50}\right.$ ca. $\left.50 \mu \mathrm{M}\right)$, cecropin $\mathrm{A}$ and $\mathrm{B}\left(\mathrm{LC}_{50} \mathrm{ca} .20 \mu \mathrm{M}\right)$ and magainine $\left(\mathrm{LC}_{50} \mathrm{ca}\right.$. $200 \mu \mathrm{M}),{ }^{3}$ CAMEL kills neoplastic cells at lower concentrations. The lower effective dose of CAMEL has therapeutic implications as it reduces the probability of side effects that are often encountered during treatment.

CAMEL, the hybrid molecule of cecropin A and melittin, does not show hemolytic activity, which often accompanies 


\section{a}
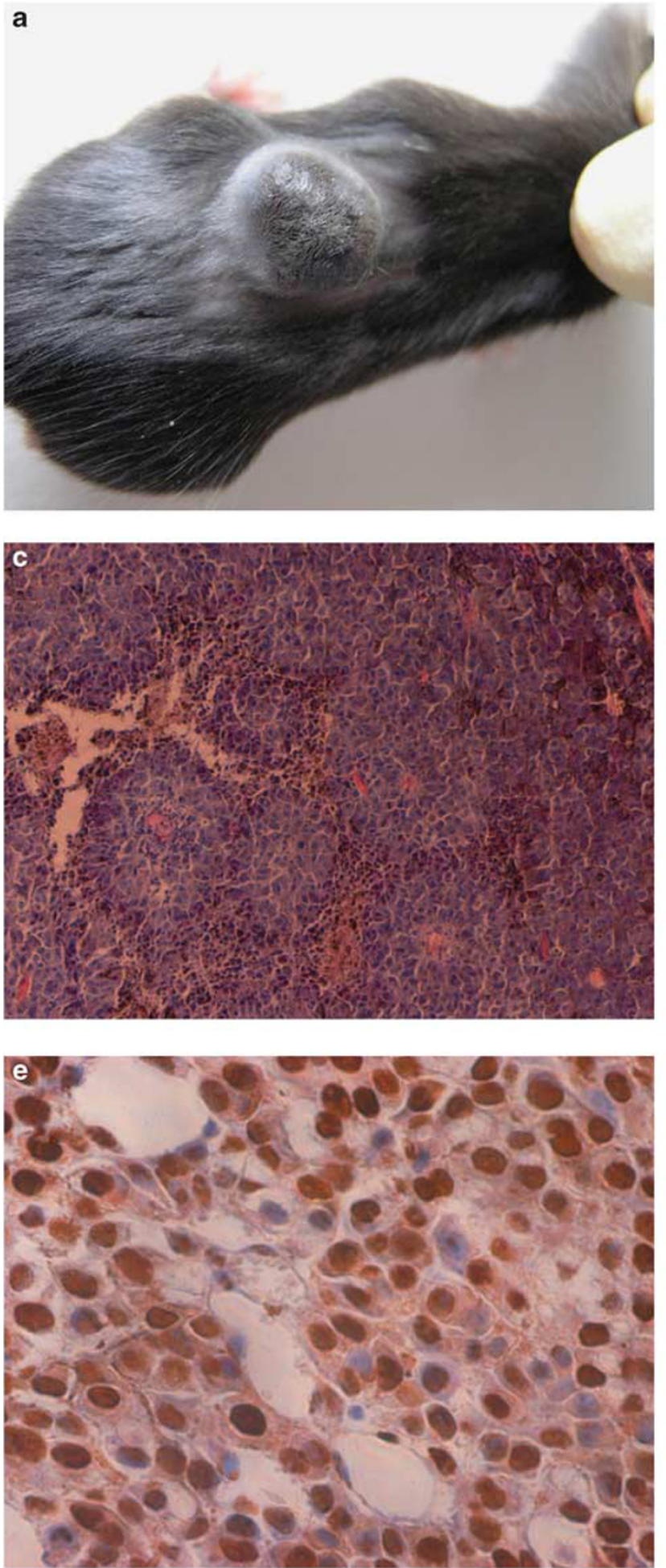

Control
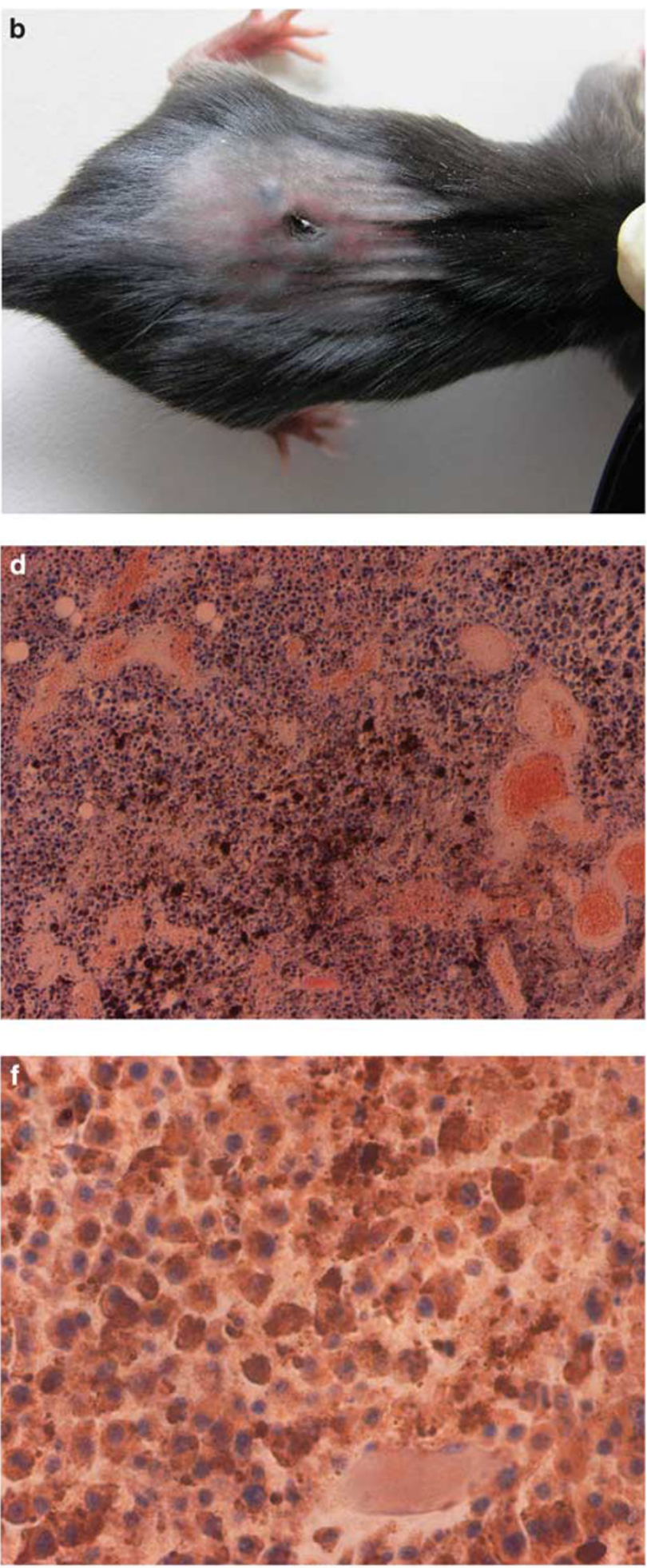

CAMEL

Figure 10 Histological tumor sections after treatment of mice with CAMEL. Mice harboring B16-F10 melanoma tumors ca. $5 \mathrm{~mm}$ in diameter received intratumoral injections of PBS ${ }^{-}$or CAMEL $\left(115 \mu \mathrm{g} / 100 \mu \mathrm{lPBS}^{-}\right)$. The peptide was administered daily on 4 consecutive days. Pictures were taken on day 15 of the experiment (a and b). (c) H\&E tumor sections from an untreated mouse (a single dose of PBS ${ }^{-}$only) and (d) H\&E tumor sections from a mouse treated with a single dose of CAMEL $\left(115 \mu \mathrm{g} / 100 \mu \mathrm{IBS}^{-}\right)$. Paraffin-embedded tumors sections were also stained with anti-HMGB1 antibody. HRP-conjugated second antibody was then added and the preparation stained with DAB solution. HMGB1 protein is shown as staining brown. In addition, the sections were hematoxylin-stained. In control tumors (e) HMGB1 protein is shown to be localized in cell nucleus, whereas, after CAMEL administration, HMGB1 is detected in both cytoplasm and extracellular space (f). 
other peptide drugs, such as melittin or magainine. ${ }^{3}$ Lysed red blood cells were found for melittin already at $0.78 \mu \mathrm{M}$, with $100 \%$ cell lysis occurring at $12.5 \mu \mathrm{M} .{ }^{13}$ Only slight erythrocyte lysis is observed in case of CAMEL at $40 \mu \mathrm{M}$, whereas at $100 \mu \mathrm{M} 30 \%$ of cells are affected after a 2-h exposure. This can

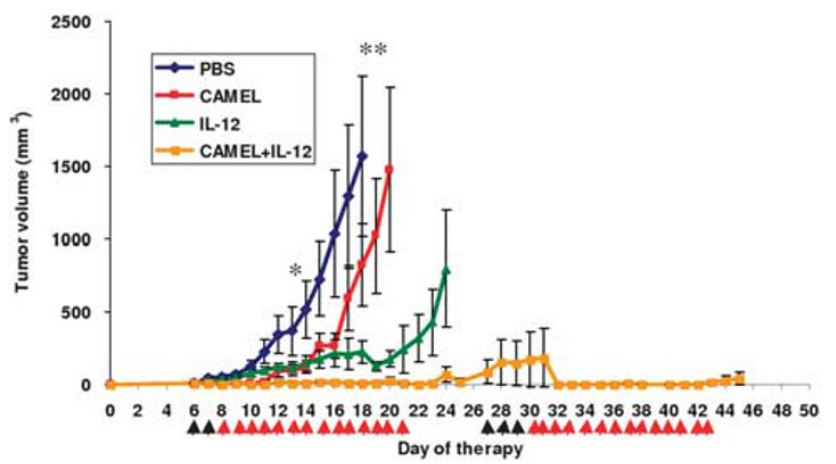

Figure 11 Effects of combined therapy with CAMEL and plasmid DNA carrying IL-12 gene on murine melanoma growth. Intratumoral CAMEL injections $\left(115 \mu \mathrm{g} / 100 \mu \mathrm{lPBS}^{-}\right)$were started on day 6 after mice's inoculation with B16-F10 cells, when tumors reached ca. $0.5 \mathrm{~mm}$ in diameter. Two injections were given. Next, the mice received for 14 days intratumoral injections of BCMGSNeo plasmid carrying IL-12 gene $(50 \mu \mathrm{g}$ DNA $/ 100 \mu \mathrm{lPBS}^{-}$). After a 5-day pause the mice were again administered CAMEL (three injections) and, lastly, plasmid DNA (for consecutive 14 days). Mice that received plasmid DNA only, CAMEL only or $\mathrm{PBS}^{-}$only were treated as control. Each treatment group had five animals. Tumor volume and survival were monitored daily. Graph shows the effect of administering peptide and IL-12-carrying plasmid in combination (orange arrowsCAMEL; green arrows-plasmid DNA). The difference in tumor volume between the group receiving CAMEL and the group receiving both CAMEL and plasmid DNA with IL-12 gene was statistically significant from day 13 of therapy $\left({ }^{*} P<0.05\right)$, and reaching ${ }^{* *} P=0.02$ on day 19 .

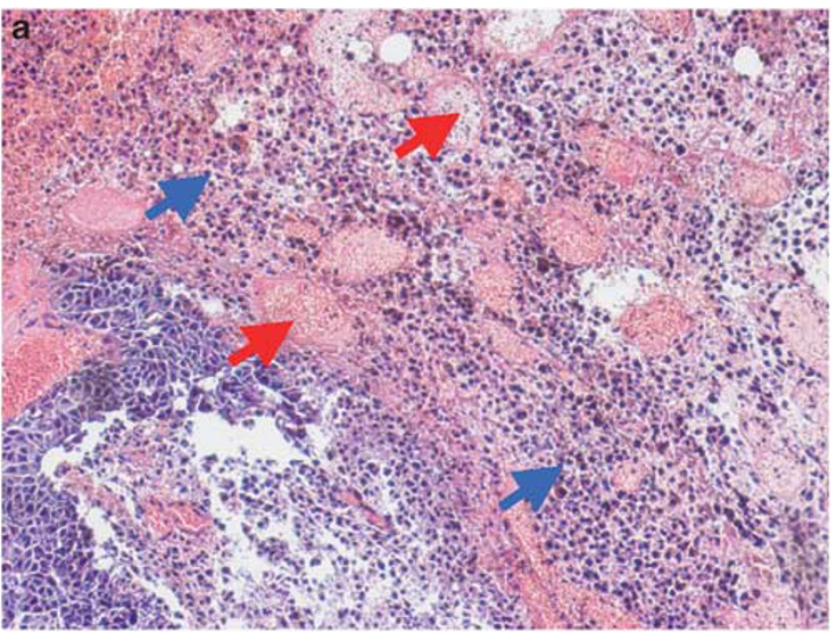

CAMEL suggest that CAMEL penetrates cells without affecting cellular membrane. No significant hemolysis of erythrocytes has been observed, even after a 24-h incubation. Studies with FITClabeled CAMEL and propidium iodide confirmed that the peptide penetrates cells and accumulates in the cytoplasm, and not in the nucleus. An increased number of cells with CAMEL peptide is observed within minutes. Nevertheless, as time elapsed, the ensuing cellular swelling and loss of membrane continuity led to red staining of cell nucleus with propidium iodide. In our opinion, after CAMEL administration and disruption of mitochondrial membranes, the loss of membrane continuity does take place in both normal and cancer cells. Disorganization of mitochondria triggers a significant drop in ATP, water influx and rupture of cells. This effect was not observed in erythrocytes that lack mitochondria. These results were corroborated with LDH release test. Administration of CAMEL at 2 or $5 \mu \mathrm{M}$ concentration did not trigger $\mathrm{LDH}$ release; however, $10 \mu \mathrm{M}$ CAMEL did increase the amount of LDH released. This suggests a loss of membrane continuity, but it is the result of mitochondrial damage, swelling and cells' rupture.

After internalization, CAMEL becomes localized on the surface of mitochondrial membrane. Because of positive charge, CAMEL strongly binds to negatively charged membranes of bacteria, mitochondria and some eukaryotic cells. This strong binding of peptidic drugs causes structural disturbances in the affected cells and ultimately leads to their destruction. ${ }^{14}$ Using flow cytometric analysis with a lipophilic cationic substance, JC-1, we observed dissipation of mitochondrial transmembrane potential after treating B16-F10 cells with CAMEL, which causes mitochondrial swelling. It suggests that CAMEL destroys mitochondrial

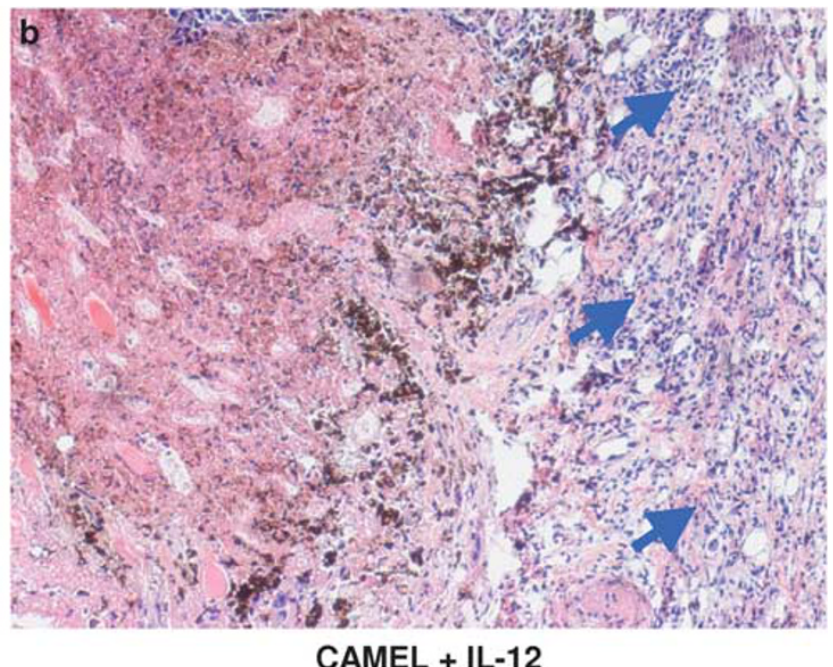

Figure 12 Histological tumor sections after treatment of mice with CAMEL and plasmid DNA with IL-12. When tumors reached ca. 5 mm in diameter, mice were given intratumoral injections of CAMEL (115 $\mu \mathrm{g} / 100 \mu \mathrm{lPBS}^{-}$; two injections) and plasmid DNA with IL-12 gene (50 $\mu \mathrm{g} / 100 \mu \mathrm{l}$; nine injections). The figure shows sections of tumor treated with CAMEL only (a) and sections of tumor treated with CAMEL and plasmid DNA with IL-12 gene (b). At $24 \mathrm{~h}$ after injections concluded the tumors were excised, fixed in $2 \%$ paraformaldehyde $(\mathrm{pH} 7.2)$ and paraffin embedded. The tumors were then sectioned into 5 - to

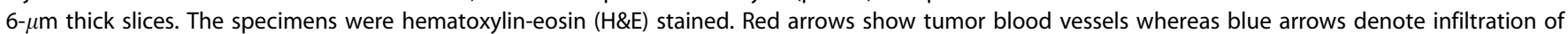
immune cells. Objective lens magnification $\times 10$. 
membranes. Despite that, CAMEL peptide did not induce caspase 3 activation through liberation of cytochrome $c$ from mitochondria and activation of caspase cascade.

Bhargava and Feix ${ }^{15}$ postulated that CAMEL destroys bacterial membrane through a detergent-like 'carpet' mechanism or by channel formation disturbing ion gradient. According to these researchers, in aqueous solutions CAMEL does not adopt any definite structure, whereas upon attaching to the membrane it forms an $\alpha$-helix that localizes ultimately within the lipid bilayer.

In the presence of CAMEL a progressive mitochondrial swelling (starting at ca. $30 \mathrm{~min}$ ) was observed, which is possibly linked with a significant depletion of cellular ATP. In our experiments the amount of ATP was decreased already after 30 min of peptide administration, reaching values below $20 \%$ after $3 \mathrm{~h}$. Depletion of ATP was proportional to the peptide amount added to samples. Lower ATP levels in the samples are indicative of cells undergoing necrotic type of death. ${ }^{16,17}$ Lower content of cellular ATP affects functioning of ion pumps (eg, potassium and calcium) and abolishes concentration-driven transport, which results in ionic imbalance in the cytosol and organelles. ${ }^{18}$ Swelling leads to cell breakdown and results in cytosol spillout. These changes are typical of necrotic cell death.

The primary aim of this study was to analyze the therapeutic effect of CAMEL in mice harboring experimental B16-F10 melanoma tumors. The results indicate significant suppression of tumor growth already after a single peptide injection. No such effect was observed when control peptide was administered. However, tumor growth inhibition persisted only if peptide administration was continuous. After cessation of therapy with CAMEL, tumors resumed uncontrolled growth after 3 to 4 days, and hence the treated mice did not survive longer than the control mice. Intravenous administration of either 115 or $200 \mu \mathrm{g}$ of CAMEL yielded a much worse therapeutic effect than direct intratumoral administration of $115 \mu \mathrm{g}$ of the peptide.

Subsequent to intratumoral administration of CAMEL, extensive necrosis was observed in tumor tissues, together with numerous foci of extravasated blood, which is suggestive of destroyed tumor vasculature. In contrast, H\&E-stained sections of tumors from control mice revealed blood vessels and neoplastic cells evenly distributed around them. In untreated tumors, the HMGB1 protein, a necrosis marker, was mainly present in cell nuclei and, to a lesser extent, in the cytoplasm. ${ }^{19}$ However, after CAMEL administration, HMGB1 protein was released from cell nucleus into cytoplasm and intercellular space. The release of HMGB1 protein causes ensuing inflammation because of the influx of lymphocytes, macrophages, neutrophils and mast cells, activation of defense mechanisms and repair of the affected tissue. ${ }^{20-22}$ The cells of the immune system provide a variety of proangiogenic factors, as well as numerous cytokines and growth factors, and this together allows formation of new blood vessels and further tumor growth. ${ }^{23}$ HMGB1 protein also activates migration of progenitor endothelial cell toward neoplastic cells. In addition, immune system cells stimulate invasiveness of neoplastic cells and their metastasis. ${ }^{24}$ All of these events result in rapid tumor regrowth, which was indeed observed during this study when CAMEL therapy was interrupted.

To prevent tumor regrowth, three cycles of five CAMEL injections with intermittent 5-day pauses were examined. This protocol extended survival of treated animals. However, when administration of the peptide was ceased, tumor growth resumed rapidly.

To obtain a more persistent cessation of tumor growth and gain further prolongation of animal survival, we finally tried a combination of CAMEL and interleukin-12, an immunostimulatory drug. The main activity of the latter is to activate the differentiation of helper $\mathrm{T}$ lymphocytes into cytotoxic ones. IL-12 activates secretion of IFN- $\gamma$ that, in turn, stimulates proliferation of T lymphocytes and NK cells and activates their cytotoxic activities. ${ }^{25}$ In addition, IL-12 inhibits formation of novel blood vessels, which is the key feature of tumor relapse. ${ }^{26,27}$ This occurs through IFN- $\gamma$ and specific interactions between lymphocytes and endothelial cells. Immunomodulatory and antiangiogenic functions of this protein make its use in anticancer therapy advantageous, especially when combined with major anticancer drugs, such as CAMEL. Combining administration of CAMEL and IL-12 gene-harboring plasmid, together with appropriate sequence of injections, allowed us to inhibit growth of experimental melanotic tumors in mice (completely destroyed tumors in $60 \%$ of the treated animals).

It seems therefore that specific combinations of necrosisinducing peptide (CAMEL) and IL-12-carrying plasmid DNA can inhibit tumor growth as well as prevent tumor relapse.

Supplementary Information accompanies the paper on the Laboratory Investigation website (http://www.laboratoryinvestigation.org)

\section{ACKNOWLEDGEMENT}

We thank A Sochanik, J Kajstura and M Zembala for invaluable suggestions and reading the manuscript. This work was supported by the Polish Ministry of Science and Higher Education, Grants No. 3P05A 16129 and No. NN401 034736.

\section{DISCLOSURE/CONFLICT OF INTEREST}

The authors declare no conflict of interest.

1. Mader JS, Hoskin DW. Cationic antimicrobial peptides as novel cytotoxic agents for cancer treatment. Expert Opin Investig Drugs 2006;15:933-946.

2. Jenssen $H$, Hamill $P$, Hancock RE. Peptide antimicrobial agents. Clin Microbiol Rev 2006;19:491-511.

3. Hoskin DW, Ramamoorthy A. Studies on anticancer activities of antimicrobial peptides. Biochim Biophys Acta 2008;1778:357-375.

4. Latham PW. Therapeutic peptides revisited. Nat Biotechnol 1999:17:755-757.

5. Monk BC, Harding DR. Peptide motifs for cell-surface intervention: application to anti-infective and biopharmaceutical development. BioDrugs 2005;19:261-278. 
6. Sato $A K$, Viswanathan $M$, Kent $R B$, et al. Therapeutic peptides: technological advances driving peptides into development. Curr Opin Biotechnol 2006;17:638-642.

7. Bogucka K, Królicka A, Kamysz W, et al. Activities of synthetic peptides against human pathogenic bacteria. Pol J Microbiol 2004;53:41-44.

8. Fields GB, Noble RL. Solid phase peptide synthesis utilizing 9-fluorenylmethoxycarbonyl amino acids. Int J Pept Protein Res 1990;35:161-214.

9. Kamysz W, Kochanska B, Kedzia A, et al. Statherin SV2 and its analogue. Synthesis and evaluation of antimicrobial activity. Polish J Chem 2002;76:801-806.

10. Frezza C, Cipolat S, Scorrano L. Organelle isolation: functional mitochondria from mouse liver, muscle and cultured fibroblasts. Nat Protoc 2007;2:287-295.

11. Bozzola JJ, Russell LD. Specimen preparation for transmission electron microscopy. In: Bozzola JJ, Russell LD (eds). Electron Microscopy: Principles and Techniques for Biologists. Jones and Bartlett Publishers Inc: London, 1999. pp 14-38.

12. Obana $\mathrm{S}$, Miyazawa $\mathrm{H}, \mathrm{Hara} \mathrm{E}$, et al. Induction of anti-tumor immunity by mouse tumor cells transfected with mouse interleukin-12 gene. Jpn J Med Sci Biol 1995;48:221-236.

13. Lee DG, Hahm KS, Park Y, et al. Functional and structural characteristics of anticancer peptide Pep27 analogues. Cancer Cell Int 2005; 5:21-34.

14. Powers JP, Hancock RE. The relationship between peptide structure and antibacterial activity. Peptides 2003;24:1681-1691.

15. Bhargava K, Feix JB. Membrane binding, structure, and localization of cecropin-mellitin hybrid peptides: a site-directed spin-labeling study. Biophys J 2004;86:329-336.
16. Golstein P, Kroemer G. Cell death by necrosis: towards a molecular definition. Trends Biochem Sci 2007;32:37-43.

17. Leist $M$, Single $B$, Castoldi $A F$, et al. Intracellular adenosine triphosphate (ATP) concentration: a switch in the decision between apoptosis and necrosis. J Exp Med 1997;185:1481-1486.

18. Zong WX, Thompson CB. Necrotic death as a cell fate. Genes Dev 2006;20:1-15.

19. Raucci A, Palumbo R, Bianchi ME. HMGB1: a signal of necrosis. Autoimmunity 2007:40:285-289.

20. Lotze MT, Tracey KJ. High-mobility group box 1 protein (HMGB1): nuclear weapon in the immune arsenal. Nat Rev Immunol 2005;5:331-342.

21. Scaffidi P, Misteli T, Bianchi ME. Release of chromatin protein HMGB1 by necrotic cells triggers inflammation. Nature 2002;418:191-195.

22. Yang $\mathrm{H}$, Wang $\mathrm{H}, \mathrm{Czura} \mathrm{CJ}$, et al. The cytokine activity of HMGB1. J Leukoc Biol 2005;78:1-8.

23. Schlueter $\mathrm{C}$, Weber $\mathrm{H}$, Meyer $\mathrm{B}$, et al. Angiogenetic signaling through hypoxia: HMGB1: an angiogenetic switch molecule. Am J Pathol 2005;166:1259-1263.

24. Ellerman JE, Brown CK, de Vera M, et al. Masquerader: high mobility group box-1 and cancer. Clin Cancer Res 2007;13:2836-2848.

25. Del Vecchio M, Bajetta E, Canova S, et al. Interleukin-12: biological properties and clinical application. Clin Cancer Res 2007;13:4677-4685.

26. Rakhmilevich AL, Hooper AT, Hicklin DJ, et al. Treatment of experimental breast cancer using interleukin-12 gene therapy combined with anti-vascular endothelial growth factor receptor-2 antibody. Mol Cancer Ther 2004;3:969-976.

27. Weiss JM, Subleski JJ, Wigginton JM, et al. Immunotherapy of cancer by IL-12-based cytokine combinations. Expert Opin Biol Ther 2007;7:1705-1721. 